\title{
53. A GEOCHEMICAL STUDY OF ORGANIC-MATTER-RICH UPPER CRETACEOUS CLAYSTONES FROM THE LOWER CONTINENTAL RISE OFF NORTH AMERICA, DEEP SEA DRILLING PROJECT HOLE 603B ${ }^{1}$
}

\author{
Rosanne M. Joyce and Edward S. Van Vleet, University of South Florida ${ }^{2}$
}

\begin{abstract}
Organic-matter-rich Upper Cretaceous claystones from DSDP Hole 603B, lower continental rise, had organic carbon values ranging from 1.7 to $13.7 \%, \mathrm{C} / \mathrm{N}$ ratios from 32 to 72 , and $\delta^{13} \mathrm{C}$ values from -23.5 to $-27.1 \%$. Lipid class maxima for the unbound alkanes $\left(C_{29}\right.$ and $\left.C_{31}\right)$, unbound fatty acids $\left(C_{28}\right.$ and $\left.C_{30}\right)$, and bound fatty acids $\left(C_{24}, C_{26}\right.$, and $\mathrm{C}_{28}$ and the strong odd-carbon and even-carbon preferences, respectively, suggested that the organic matter in these sediments was partially the result of input from continental plant waxes. Transport of the organic-matter-rich sediments to the deep sea from the near-shore environment probably resulted from turbiditic flow under oxygen-stressed conditions.
\end{abstract}

\section{INTRODUCTION}

Historically, the Upper Cretaceous has been described as a period of numerous global events. A great eustatic transgression was prompted by diminishing latitudinal temperature gradients (Ryan and Cita, 1977; Van Graas, 1983), and the consequent stagnation of the oceans led to the expansion of the oxygen-minimum zone (Jenkyns, 1980). As the continental shelf broadened, a flux and widespread deposition of terrestrially derived organic material occurred along the prograding margin (Jenkyns, 1980). Based on the premise that nutrient enrichment of surface waters diminished from waning oceanic circulation (Fischer and Arthur, 1977) and taking into account organic carbon accumulation rates in deep-sea deposits, Bralower and Thierstein (1984) proposed that primary productivity rates must have been lower during the Cretaceous than in today's oceans. However, in this oxygenstressed oceanic system, even marine-derived organic material may have been preserved in the underlying sediments.

The goals of the present research addressed the following questions, based upon analytical interpretations of organic carbon and lipid in sediment samples collected from the lower continental rise east of North America: What is the provenance of the organic matter? Do constituents of the selected lipid fractions reflect the origin of the bulk organic matter? Do the lipid fractions give any evidence of microbial alteration? What are the paleoenvironmental implications of this study?

\section{EXPERIMENTAL METHODS}

Deep Sea Drilling Project (DSDP) core samples were obtained by the scientific party aboard the Glomar Challenger. DSDP Hole 603B is located on the lower continental rise, $435 \mathrm{~km}$ east of Cape Hatteras, North Carolina (latitude $35^{\circ} 29.71^{\prime} \mathrm{N}$; longitude $70^{\circ} 01.71^{\prime} \mathrm{E}$ ) at a water depth of $4643 \mathrm{~m}$. Four of the samples analyzed in this study are Ce-

${ }^{1}$ van Hinte, J. E., Wise, S. W., Jr., et al., Init. Repts. DSDP, 93: Washington (U.S. Govt, Printing Office).

2 Address: Department of Marine Science, University of South Florida, 1407 th Avenue South, St. Petersburg, FL 33701.
nomanian-Turonian black carbonaceous claystones (1127 to $1146 \mathrm{~m}$ ) and a fifth sample is a Coniacian-Santonian variegated claystone (1081 m; Table 1). A stratigraphic summary of Hole 603B is provided in the Site 603 chapter (this volume).

Lipid was solvent-extracted by refluxing $50-100 \mathrm{~g}$ of sediment in a fivefold volume excess of 70:30:15 methanol/toluene/water for three hours after sonication (Joyce, 1985). After partitioning and hexane extraction, the unbound lipid extract was concentrated to near dryness by rotary evaporation and diluted to known volume. An aliquot of the unbound lipid was partitioned to obtain five lipid fractions employing a modified serial-elution, silica-gel, column-chromatography procedure (Wakeham, 1982; Joyce, 1985). Column fraction eluants corresponded to aliphatic hydrocarbons, aromatic hydrocarbons, wax esters/sterol esters, triacylglycerols/fatty alcohols/sterols, and fatty acids/phospholipids. Fatty acids were methylated with boron trifluoride in methanol (Metcalfe et al., 1966). Derivatized components were purified by thinlayer chromatography on silica gel-G developed with $95: 5: 1$ petroleum ether/ethyl ether $/ \mathrm{NaOH}$ and visualized with bromthymol blue. Experiments with authentic fatty acid standards were conducted to determine the analytical reliability of this derivatization procedure. The percent recovery from methylation was $56.5 \pm 10.4 \%$.

Residual sediment was subjected to a second extraction of $0.5 \mathrm{~N}$ $\mathrm{KOH}$ in methanol/toluene to obtain the bound lipid fraction. Separation, derivatization, and purification of the lipid classes were performed as previously described. Total lipid and lipid fraction concentrations were determined by weighing aliquots of unbound and bound lipid in tared Teflon weighing boats on a five-place Mettler balance after drying to constant weight under a stream of nitrogen.

Identification and quantitative determinations of lipids were made employing splitless injection capillary gas-liquid chromatography. A Hewlett-Packard 5880A FID gas chromatograph (GC) equipped with

Table 1. Site description of Hole 603B, lower continental rise, U.S. East Coast.

\begin{tabular}{cccc}
\hline $\begin{array}{c}\text { Core-Section } \\
\text { (interval in cm) }\end{array}$ & $\begin{array}{c}\text { Depth } \\
(\mathrm{m})\end{array}$ & Lithology & $\begin{array}{c}\text { Age } \\
(\mathrm{Ma})\end{array}$ \\
\hline $29-1,48-53$ & 1050 & $\begin{array}{c}\text { Variegated clay- } \\
\text { stone }\end{array}$ & $\begin{array}{c}\text { Coniacian- } \\
\text { Santonian } \\
(84-89)\end{array}$ \\
$33, \mathrm{CC}, 1-8$ & 1127 & $\begin{array}{c}\text { Black carbonaceous } \\
\text { claystones }\end{array}$ & $\begin{array}{c}\text { Turonian } \\
(89-91)\end{array}$ \\
$34-1,13-16$ & 1128 & $\begin{array}{c}\text { Black carbonaceous } \\
\text { claystones } \\
\text { Cenomonian } \\
(91-98)\end{array}$ \\
$34-2,136-139$ & 1130 & $\begin{array}{c}\text { Black carbonaceous } \\
\text { claystones } \\
\text { Cenomanian } \\
(91-98) \\
\text { B6-1,39-43 carbonaceous } \\
\text { claystones }\end{array}$ & $\begin{array}{c}\text { Cenomanian } \\
(91-98)\end{array}$ \\
\hline
\end{tabular}




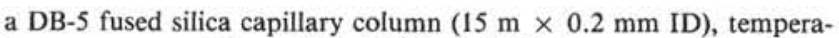
ture programmed from 90 to $255^{\circ} \mathrm{C}$ at $4^{\circ} \mathrm{C} / \mathrm{min}$., was used with hydrogen as a carrier gas $(3 \mathrm{ml} / \mathrm{min}$.) and make-up gas $(27 \mathrm{ml} / \mathrm{min}$.). Temperature settings for the injection port and detector were 240 and $300^{\circ} \mathrm{C}$, respectively. Individual compounds were identified by comparison of retention times with those of authentic standards. Quantification of individual constituents, based on relative percentages of integrated peaks, was extrapolated to the gravimetrically determined total lipid fraction weight. Analytical variation in sample replicate quantification by GC analysis generally ranges from \pm 10 to $37 \%$ (Farrington and Tripp, 1977; Prahl et al., 1980). Lipid identification was confirmed by gas chromatography-mass spectrometry (GC-MS) using authentic standards, retention times, and library mass spectra.

Stable carbon isotope analyses were performed on 1-g sediment subsamples that were oven dried and acidified $(10 \% \mathrm{HCl})$ for carbonate removal. Sediment was combusted at $800^{\circ} \mathrm{C}$ in a Lindberg combustion furnace over copper oxide in an oxygen atmosphere. Carbon dioxide was purified and collected in a vacuum line by liquid nitrogen traps, as described by Craig (1953). Isotope ratio measurements of the samples were performed on a Finnegan MAT 250 isotope ratio mass spectrometer. Results are reported relative to the Chicago PDB standard (Craig, 1953) in terms of $\delta^{13} \mathrm{C}$ defined as:

$$
\delta^{13} \mathrm{C} \%=\left[\frac{{ }^{13} \mathrm{C} /{ }^{12} \mathrm{C} \text { sample }}{{ }^{13} \mathrm{C} /{ }^{12} \mathrm{C} \text { standard }}-1\right] \times 1000 .
$$

Average analytical variability of sample preparation and stable carbon isotope ratio analysis is generally $\pm 0.2 \%$ (Mangini, 1983).

Elemental analyses were performed on acidified, oven-dried, and tared 1-g sediment subsamples. Sediment was combusted at $1000^{\circ} \mathrm{C}$ employing a Carlo-Erba Model 1106 Elemental Analyzer. Elemental peak integration and data were processed on an Osborne 1 computer and Carlo-Erba DP 110 data processor. Results of the analyses included total percent organic carbon, nitrogen, and hydrogen. Analytical variation of sample analysis is generally $\pm 20 \%$ (DeFlaun, personal communication, 1985).

\section{RESULTS}

Organic geochemical data for the Upper Cretaceous sediment samples from DSDP Hole 603B are summarized in Table 2 (more detailed results can be found in Joyce, 1985). Total organic carbon (TOC) was lowest $(1.7 \%)$ in the Coniacian-Santonian variegated claystone (603B-29-1) and higher (3.4-13.7\%) in the CenomanianTuronian black shales (Sample 603B-33,CC, Sections 603B-34-1, 603B-34-2, 603B-36-1). Organic carbon/organic nitrogen atomic ratios $(\mathrm{C} / \mathrm{N})$ were highest $(72)$ in the variegated claystone and lower (32-44) in the black shale samples (Table 2). Increasingly lighter $\delta^{13} \mathrm{C}$ values relative to Chicago PDB $(-23.5$ to $-24.7 \%$ ) were measured in Sections 603B-34-2 to 603B-29-1. Section 603B36-1 was found to have the lightest value in the sample set $(-27.1 \%)$. The concentration of total extractable lip- id was variable, although lipid proportions relative to the content of total organic matter decreased from Section 603B-36-1 to 603B-29-1 (4.8-1.5\%). The unbound lipid fraction represented the greatest proportion of the total (solvent-extractable and saponifiable) lipid in each sample (73-94\%).

Concentrations of nonaromatic hydrocarbons in these claystone samples ranged from 4 to $336 \mu \mathrm{g} / \mathrm{g}$, and generally comprised $<12 \%$ of the unbound lipid (Table 3 ). Compounds in this hydrocarbon fraction ranged from $\mathrm{C}_{16}$ to $\mathrm{C}_{33}$ in each sample (Fig. 1). Monoenoic compounds $(18: 1,20: 1)$ were detected only in sediment sampled from Sections 603B-33,CC and 603B-34-1. Original plans for stereochemical analysis of the isoprenoid compounds, pristane and phytane, were unsuccessful because of their absence or low relative abundance. Bound nonaromatic hydrocarbons accounted for $\leq 7 \%$ of the alkaline-hydrolyzed lipid (Table 3); the largest percentage was measured in the variegated claystone (603B-29-1). Concentrations of the bound hydrocarbons ranged from $<1$ to $15 \mu \mathrm{g} / \mathrm{g}$; only in the variegated claystone did the bound lipid concentration exceed the unbound lipid concentration. Bound $n$-alkanes generally ranged from $\mathrm{C}_{18}$ to $\mathrm{C}_{33}$, with predominating peaks at $\mathrm{C}_{20}$ or $\mathrm{C}_{22}$ (Fig. 2). A compilation of data from gas chromatographic analysis of bound and unbound $n$-alkanes is presented in Table 3 .

Fatty acids comprised $7-29 \%$ of the unbound lipid extract and represented sediment concentrations of 55$370 \mu \mathrm{g} / \mathrm{g}$ (Table 4). The distribution of unbound fatty acids generally ranged from $\mathrm{C}_{14}$ to $\mathrm{C}_{32}$ (Fig. 3). The variegated claystone had a peak of maximum abundance at $\mathrm{C}_{30}$, whereas the black shales maximized at $\mathrm{C}_{16}$ or $\mathrm{C}_{18}$. Monoenoic fatty acids $(18: 1,20: 1,22: 1,30: 1)$ were detected in black shale samples from Sections 603B-34-1 and 603B-36-1. Trace levels of anteiso (ai) fatty acids $\left(\mathrm{aiC}_{17: 0}, \mathrm{aiC}_{19: 0}, \mathrm{aiC}_{21: 0}\right)$ were found in both the variegated claystone and black shale samples. Gravimetric analysis of the fatty acid fraction in Section 603B-34-2 failed to produce results after several attempts; therefore its contribution to the total unbound lipid extract is not known. The fatty acid concentration may have been below gravimetric detection. The contribution of bound fatty acids to the total lipid was one to three orders of magnitude less than the respective unbound fatty acid fractions. Fatty acids comprised $<1-14 \%$ of the bound lipid extract and represented sediment concentrations of $<1-10 \mu \mathrm{g} / \mathrm{g}$. Dominance of the fatty acid distributions varied among the cores (Fig. 4). A summary of data re-

Table 2. Organic geochemical data, DSDP Hole 603B samples, lower continental rise, U.S. East Coast.

\begin{tabular}{lccccc}
\hline & $29-1,48-53$ & $33, C C, 1-8$ & $34-1,13-116$ & $34-2,136-139$ & $36-1,39-43$ \\
\hline Sub-bottom depth (m) & 1050 & 1127 & 1128 & 1130 & 1146 \\
TOC $(\%)$ & 1.7 & 3.4 & 13.7 & 4.8 & 3.9 \\
C/N ratio & 72.0 & 38.6 & 43.8 & 40.0 & 32.0 \\
$\delta^{13} \mathrm{C}(\% \circ)$ & -24.73 & -24.68 & -23.62 & -23.47 & -27.08 \\
Total lipid (mg $/ \mathrm{g})$ & 0.26 & 0.73 & 3.25 & 1.36 & 1.85 \\
Lipid in TOC $(\%)$ & 1.5 & 2.2 & 2.4 & 2.8 & 4.8 \\
Bound in total lipid (\%) & 27 & 7 & 6 & 19 & 9 \\
\hline
\end{tabular}

a Total organic carbon.

b Organic carbon to organic nitrogen atomic ratio. 
Table 3. Gravimetric and gas chromatographic data on unbound and bound nonaromatic hydrocarbon fractions, Hole 603B, lower continental rise, U.S. East Coast.

\begin{tabular}{|c|c|c|c|c|c|}
\hline \multirow[b]{2}{*}{ Lipid fractions } & \multicolumn{5}{|c|}{ Core-Section } \\
\hline & $29-1^{a}$ & $33, \mathrm{CC}^{\mathrm{b}}$ & $34-1^{c}$ & $34-2^{\mathrm{C}}$ & $36-1^{c}$ \\
\hline \multicolumn{6}{|c|}{ Unbound nonaromatic $\mathrm{HC}^{\mathrm{d}}$} \\
\hline$\mu \mathrm{g} / \mathrm{g}$ dry sediment & 4 & 27 & 336 & 44 & 134 \\
\hline Unbound lipid (\%) & $2(3)^{e}$ & $4(3)$ & $11(15)$ & $4(5)$ & $8(4)$ \\
\hline$<\mathrm{C}_{25}(\%)$ & 2 & 4 & 2 & 2 & 2 \\
\hline$\geq C_{25}(\%)$ & 5 & 5 & 4 & 5 & 4 \\
\hline Unidentified (\%) & 6 & 44 & 40 & 47 & 20 \\
\hline $\operatorname{UCM}^{f}(\%)$ & 87 & 47 & 54 & 46 & 74 \\
\hline $\mathrm{OEP}^{\mathrm{g}}\left(\mathrm{C}_{17}-\mathrm{C}_{21}\right)$ & 1.0 & 0.1 & 0.9 & 0.4 & 0.7 \\
\hline $\operatorname{OEP}\left(\mathrm{C}_{27}-\mathrm{C}_{31}\right)$ & 8.0 & 2.2 & 2.0 & 1.7 & 5.8 \\
\hline $\mathrm{C}_{29} / \mathrm{C}_{17}$ & 21 & 17 & 33 & 50 & 4 \\
\hline Pristane/phytane & 1.0 & 0.8 & 0.4 & 0.3 & 0.5 \\
\hline
\end{tabular}

Bound nonaromatic $\mathrm{HC}$

\begin{tabular}{lccrrr}
$\mu \mathrm{g} / \mathrm{g}$ dry sediment & 5 & $<1$ & 5 & 15 & 3 \\
Bound lipid (\%) & 7 & $<1$ & 3 & 6 & 2 \\
Unbound/bound ratio & $<1$ & 27 & 67 & 3 & 4 \\
$<\mathrm{C}_{25}(\%)$ & 13 & 16 & 15 & 19 & 7 \\
$\geq \mathrm{C}_{25}(\%)$ & 7 & 11 & 2 & 4 & 2 \\
Unidentified (\%) & 11 & 49 & 54 & 45 & 70 \\
$\mathrm{UCM}^{\mathrm{f}}(\%)$ & 69 & 24 & 29 & 32 & 22 \\
$\mathrm{OEPP}^{\mathrm{g}}\left(\mathrm{C}_{17}-\mathrm{C}_{21}\right)$ & $<0.1$ & 0.1 & $\mathrm{NC}$ & $\mathrm{NC}$ & $\mathrm{NC}$ \\
$\mathrm{OEP}\left(\mathrm{C}_{27}-\mathrm{C}_{31}\right)$ & 1.7 & 0.8 & 0.3 & 1.1 & $0.6^{\mathrm{i}}$ \\
$\mathrm{C}_{29} / \mathrm{C}_{17}$ & $\mathrm{NC}$ & $\mathrm{NC}$ & $\mathrm{NC}$ & $\mathrm{NC}$ & $\mathrm{NC}$ \\
\hline
\end{tabular}

a Five replicates.

b Four replicates.

c Three replicates.

d Hydrocarbons.

e Standard deviation.

sulting from gas chromatographic analyses for bound fatty acid and unbound fatty acid fractions is presented in Table 4.

\section{DISCUSSION}

\section{Organic Matter Description}

The upper Cretaceous has been described as a period of global warming and waning oceanic circulation (Ryan and Cita, 1977). A continuation of geoeustatic transgressions that began in the Lower Cretaceous was responsible for maximum heights in sea level. At this time, terrigenous detritus, which had been accumulating along the prograding continental margin, was swept to the deep sea (Schlee and Jansa, 1981) in pulses of mass-wasting events (Site 603 chapter, this volume). These events, coupled with the expansion of the oxygen-minimum zone, led to the common generation of shales in these organicmatter-rich sediments.

Upper Cretaceous sediments from DSDP Hole 603B were analyzed to assess the paleoenvironmental conditions during organic matter deposition and to determine the extent of terrigenous and marine contribution to the organic matter and selected lipid fractions. Fluctuations in the total organic carbon content of these sediments may be indicative of the prevailing reducing conditions in the near-shore environment prior to deep-sea emplacement. The Coniacian-Santonian variegated claystone (603B-29-1) had a total organic carbon content of $1.7 \%$, and the Cenomanian-Turonian black shales had TOC values ranging from 3.4 to $13.7 \%$. Evidence provided by

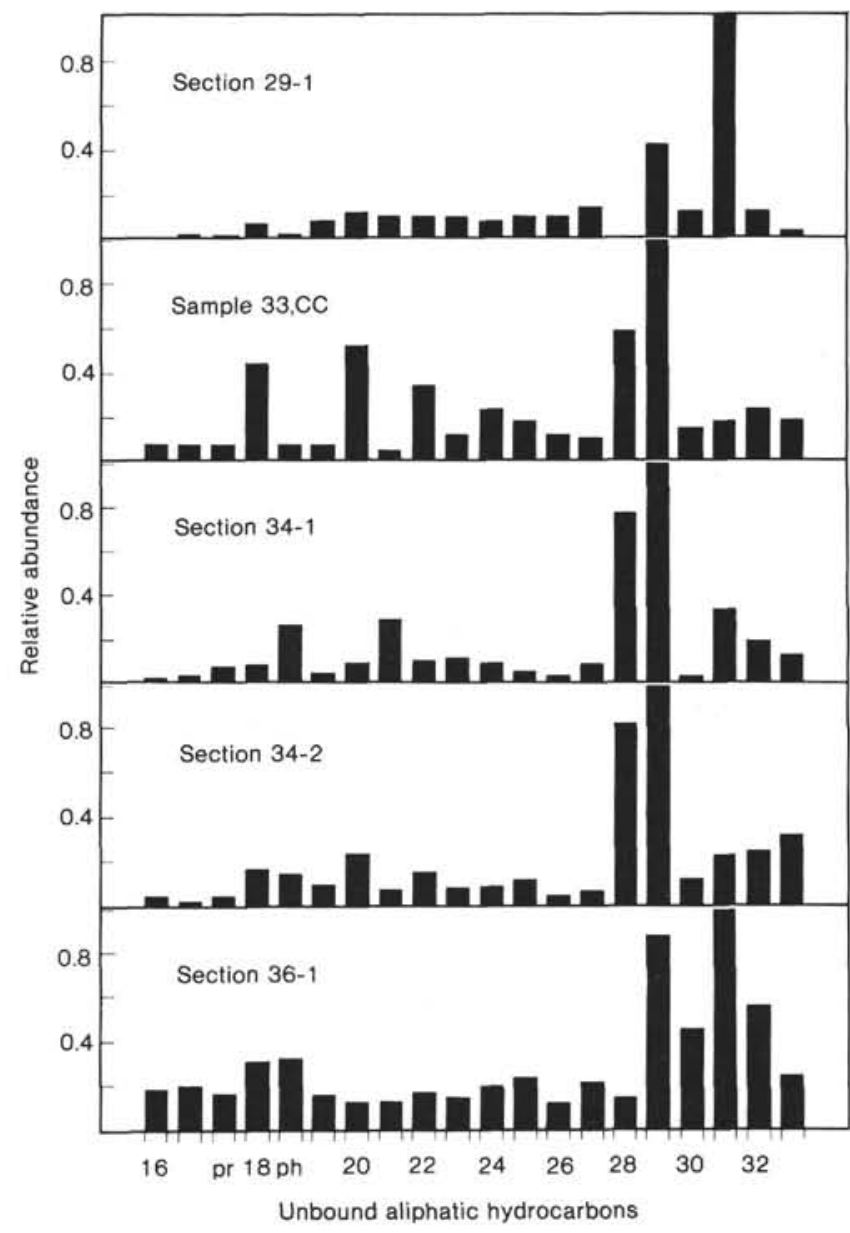

Figure 1. Distribution and relative abundances of unbound aliphatic hydrocarbons, Hole 603B.

the Leg 93 shipboard party indicated that these claystones were turbiditically emplaced, and probably represent isolated mass-wasting events (Doyle, personal communication). Conditions in the near-shore environment and lower continental rise following turbiditic emplacement must have favored organic matter preservation, because values $>0.6 \%$ TOC (Katz and Elrod, 1983) are not common for deep-sea sediments. High oxygen requirements demanded by organic matter lead to the destruction of the oxidizing potential of the sediments (Brassell, 1984). Although the presence of black shales does not necessitate an environment totally devoid of oxygen (Katz and Elrod, 1983), lack of evidence for bioturbation in the sample set supports the idea of an oxygenstressed system.

Data from elemental analyses can provide information on the source of the organic matter. $\mathrm{C} / \mathrm{N}$ ratios between 10 and 15 result from the remineralization of nitrogen in marine organic matter (Muller, 1977), and values $>15$ result from the paucity of nitrogenous compounds in higher plant lignin and cellulose (Meyers et al., in press). $\delta^{13} \mathrm{C}$ values ranging from -23 to $-33 \%$ are found in terrestrial plants utilizing the Calvin-Benson photosynthetic pathway, a maximum ${ }^{13} \mathrm{C}$ fractionation mechanism. Although the $\delta^{13} \mathrm{C}$ of marine planktonic organisms may range from -6 to $-31 \%$, most warm- 


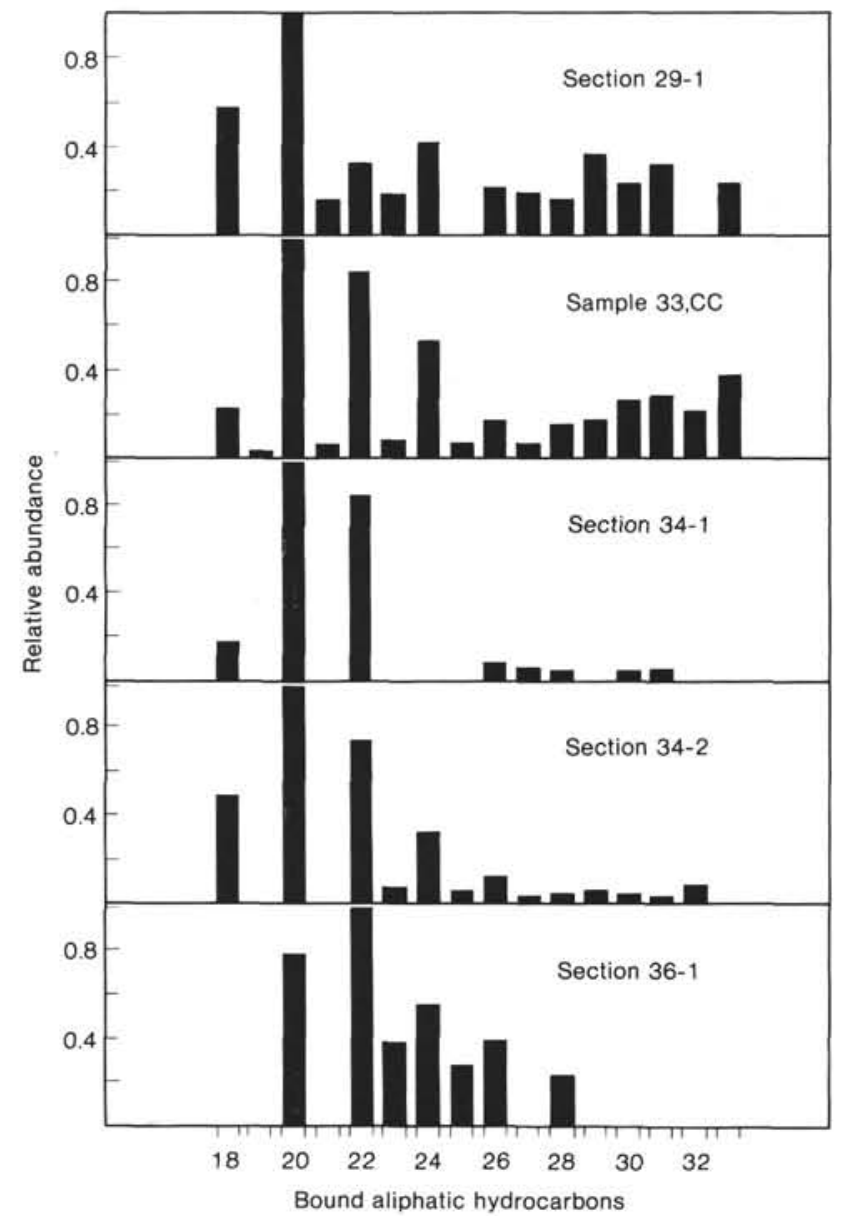

Figure 2. Distribution and relative abundances of bound aliphatic hydrocarbons, Hole 603B.

water plankton have values between -17 and $-22 \% 0$ (Anderson and Arthur, 1983). As global temperatures were thought to have been warm and equitable during the Upper Cretaceous (Ryan and Cita, 1977), warm-water plankton probably dominated the waters of the young North Atlantic Ocean and had stable carbon isotope values typical of warm-water organisms.

Elemental and lipid analyses indicated that the source of the organic matter in these Upper Cretaceous sediments was primarily terrigenous in nature. This premise is based on $\mathrm{C} / \mathrm{N}$ ratios ranging from 32 to 72 , values that may represent nitrogen-poor, terrestrially derived plant detritus. The $\delta^{13} \mathrm{C}$ values ranged from -23.5 to $-27.1 \%$. A simplistic interpretation of the $\delta^{13} \mathrm{C}$ value distribution is variable mixing of terrigenous organic matter with marine organic matter. The isotopically lighter value in Section 603B-36-1 (-27.1\%) may represent a greater contribution of terrigenous organic material to the total organic matter content, whereas the heavier value measured in Section 603B-34-2 (-23.5\%0) may represent dilution of the terrigenous organic material by marine organic matter.

\section{Unbound Nonaromatic Hydrocarbons}

Unbound nonaromatic hydrocarbons generally comprised $<12 \%$ of the total extractable lipid in Hole 603B
Table 4. Gravimetric and gas chromatographic data on unbound and bound fatty acid fractions, DSDP Hole 603B, lower continental rise, U.S. East Coast.

\begin{tabular}{|c|c|c|c|c|c|}
\hline \multirow[b]{2}{*}{ Lipid fractions } & \multicolumn{5}{|c|}{ Core-Section } \\
\hline & $29-1$ & $33, \mathrm{CC}$ & $34-1$ & $34-2$ & $36-$ \\
\hline \multicolumn{6}{|l|}{ Unbound fatty acids } \\
\hline$\mu \mathrm{g} / \mathrm{g}$ dry sediment & 55 & 122 & 213 & $\mathrm{ND}^{\mathrm{a}}$ & 370 \\
\hline Unbound lipid (\%) & 29 & 18 & 7 & ND & 22 \\
\hline$<\mathrm{C}_{22}(\%)$ & 2 & 6 & 20 & 0 & \\
\hline$\geq C_{22}(\%)$ & 9 & 5 & 13 & 2 & $<1$ \\
\hline Anteiso $(\%)$ & $\operatorname{tr}^{\mathrm{b}}$ & 1 & 1 & 0 & \\
\hline Monoenoic (\%) & 0 & 0 & tr & 0 & \\
\hline Unidentified $(\%)$ & 45 & 38 & 28 & 40 & \\
\hline $\mathrm{UCM}^{\mathrm{c}}(\%)$ & 44 & 50 & 38 & 58 & \\
\hline EOP $\left(C_{16}-C_{20}\right)^{d}$ & $\mathrm{NC}^{\mathrm{e}}$ & 2.4 & 6.4 & NC & \\
\hline $\mathrm{EOP}\left(\mathrm{C}_{22}-\mathrm{C}_{26}\right)$ & 1.6 & 2.1 & 1.7 & 2.1 & \\
\hline $\mathrm{C}_{26} / \mathrm{C}_{16}$ & NC & 0.5 & 0.7 & $\mathrm{NC}$ & $\mathrm{N}$ \\
\hline
\end{tabular}

Bound fatty acids

$\mu \mathrm{g} / \mathrm{g}$ dry sediment
Bound lipid $(\%)$
Unbound/bound ratio
$<\mathrm{C}_{22}(\%)$
$\geq \mathrm{C}_{22}(\%)$
Anteiso $(\%)$
Monoenoic $(\%)$
Unidentified $(\%)$
UCM $(\%)$
EOP $\left(\mathrm{C}_{16}-\mathrm{C}_{20}\right)$
EOP $\left(\mathrm{C}_{22}-\mathrm{C}_{26}\right)$
$\mathrm{C}_{26} / \mathrm{C}_{16}$

$\begin{array}{rrrrr}<1 & 7 & 10 & 10 & 3 \\ <1 & 14 & 5 & 4 & 2 \\ 55 & 17 & 21 & \mathrm{NC} & 123 \\ 7 & 2 & 14 & 1 & 4 \\ 22 & 4 & 5 & 9 & 7 \\ <1 & 1 & <1 & 0 & <1 \\ 7 & 3 & 6 & 1 & 2 \\ 34 & 38 & 59 & 38 & 46 \\ 30 & 52 & 15 & 51 & 40 \\ 6.8 & 5.8 & 22.1 & \mathrm{NC} & \mathrm{NC} \\ 2.2 & 2.9 & 2.4 & 2.5 & 3.1 \\ 0.7 & 2.2 & 0.1 & 6.3 & 0.4\end{array}$

a Not detected.

d Even-odd predominance.

c Unresolved complex mixture.

e Not calculated, insufficient data.

samples (Table 3). Concentrations of $n$-alkanes corresponded with those measured in organic-matter-rich Upper Cretaceous claystones from the northwestern Atlantic (Simoneit, 1979).

The $n$-alkane distribution in the Coniacian-Santonian variegated claystone (603B-29-1) was dominated by $\mathrm{C}_{29}$ and $\mathrm{C}_{31}$. These compounds are the most frequently observed alkanes in higher plant waxes (Tulloch, 1976; Fig. 1). Maxima at $C_{31}$ have been observed in other deepsea environments including DSDP Site 532B, Walvis Ridge (Joyce, 1985) and DSDP Site 386, northwest Atlantic (Erdman and Schorno, 1979). Continental plant wax maxima in deep ocean sediments signify the extent to which terrestrial source indicators can be preserved given the proper depositional environment.

The $\mathrm{C}_{29} / \mathrm{C}_{17}$ ratio of 21 and the odd-even predominance index (OEP) are other source indicators that support the contribution of terrestrial organic matter to this unbound lipid fraction. The OEP is expressed as follows:

$$
\mathrm{OEP}=\frac{\left(\mathrm{C}_{i}+6 \mathrm{C}_{i+2}+\mathrm{C}_{i+4}\right)^{-1^{i+1}}}{\left(4 \mathrm{C}_{i+1}+4 \mathrm{C}_{1+3}\right)}
$$

$\mathrm{C}_{i}$ is the relative percentage of an $n$-alkane containing $i$ carbons per molecule, where $i$ represents the number of carbon atoms per compound. The ratio incorporates the weight percentages of five consecutive alkanes centered upon the alkane containing $i+2$ carbon atoms (Scalan and Smith, 1970). 


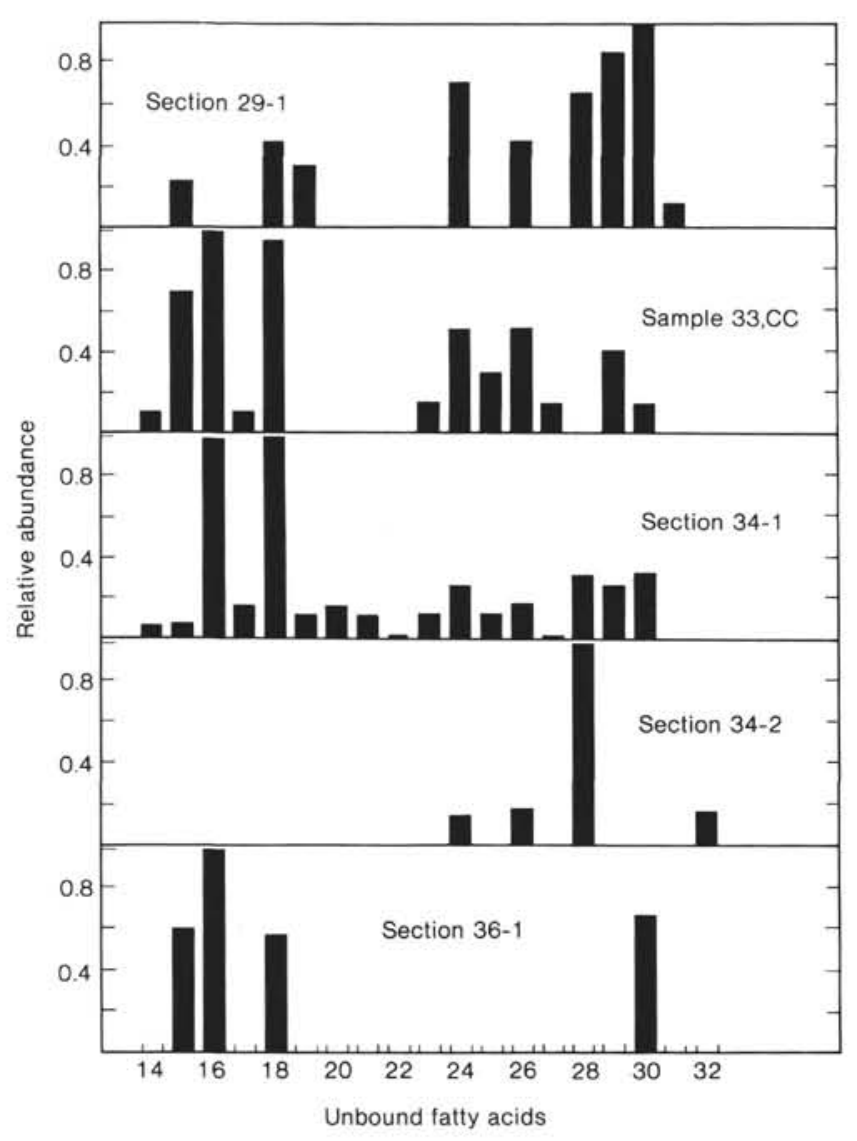

Figure 3. Distribution and relative abundances of unbound fatty acids, Hole 603B.

The odd-carbon predominance of the long-chain alkanes, $\mathrm{C}_{27}-\mathrm{C}_{31}(\mathrm{OEP}=8.0)$, suggested an early stage of organic carbon maturation (Deroo et al., 1979; Table 3). The lack of odd-even predominance for $\mathrm{C}_{17}-\mathrm{C}_{21}$ (OEP $=1.0$ ) in this sample may represent the distribution common to continentally derived plant waxes (Hunt, 1979), which may have had a minimal input to this lipid fraction.

Unbound hydrocarbons in the black shale samples were dominated by $\mathrm{C}_{29}$ in Sections 603B-33,CC, 603B-34-1, and 603B-34-2 and $\mathrm{C}_{31}$ in Section 603B-36-1 (Fig. 1). The long-chain alkanes in each sample were odd-carbon predominated, with values ranging from 1.7 (603B-34-2) to 5.8 (603B-36-1) (Table 3). As discussed before, these maxima and distributions typify inputs from plant waxes (Tulloch, 1976). In Section 603B-33,CC, compounds $<\mathrm{C}_{25}$ were as abundant $(4 \%)$ as the higher molecular weight compounds $(5 \%)$ with the short-chain distribution dominated by $\mathrm{C}_{20}$ and the OEP $=0.1$. Similar predominances by short-chain, even-carbon alkanes have been observed in black shales from other DSDP sites (Simoneit, 1979; Erdman and Schorno, 1979). This distribution may have resulted from inputs by biodegraded algae (Simoneit, 1979), geologically older sediment, or nonphotosynthetic bacteria (Hunt, 1979).

Sections 603B-34-1 and 603B-34-2 were similar in their respective alkane distributions and relative abundances (Fig. 1). Dominance of the $n$-alkanes by terrestrial sources of organic matter was evident from a number of GC parameters, including peaks of maximum abundance at

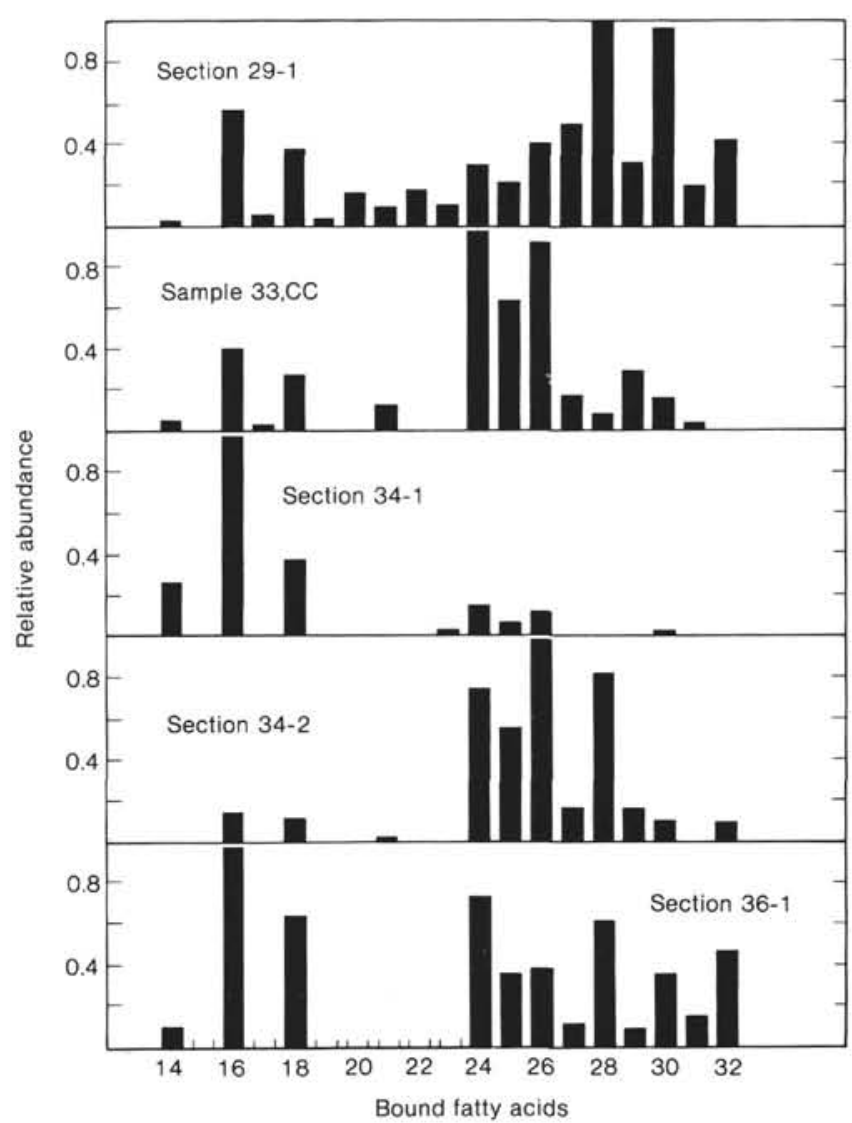

Figure 4. Distribution and relative abundances of bound fatty acids, Hole 603B.

$C_{29}$, compounds $\geq C_{25}$ that were $2-3 \%$ more abundant than compounds $<\mathrm{C}_{25}, \mathrm{C}_{29} / \mathrm{C}_{17}$ ratios of 33 and 50 , and OEPs $\left(\mathrm{C}_{27}-\mathrm{C}_{31}\right)$ of 2.0 and 2.7 , respectively.

Section 603B-36-1 differed from the other black shale samples in several parameters. The $n$-alkane maximum of $\mathrm{C}_{31}$ and OEP of $5.8\left(\mathrm{C}_{27}-\mathrm{C}_{31}\right)$ suggested a different input source by terrestrial plant waxes (Table 3). Although compounds $\geq C_{25}$ were twofold more abundant, shorter-chain compounds were relatively more abundant than in the other sediment samples.

Although double-bond reduction has been reported to occur within recently deposited sediments (Matsuda and Koyama, 1977; Van Vleet and Quinn, 1979), both monoenoic $\mathrm{C}_{18}$ and $\mathrm{C}_{20}$ were detected in two black shale samples (Table 3), albeit in lower relative abundances $(\leq 0.08)$ than the saturated alkanes. This evidence suggests that favorable conditions, such as organic-matter richness, preserve double bonds to subsurface depths as great as $1000 \mathrm{~m}$. Similar findings have been recorded from analyses of other deep-sea sediments (Boon et al., 1980). The source of the monoenoic compounds cannot be assessed without identification of double-bond position and configuration (Boon et al., 1977; Matsuda and Koyama, 1977).

Contribution of terrestrial plant material to the continental shelf from sea-level transgression, consequent turbiditic pulsing to the deep sea, and prevailing sediment anoxia is supported by nonaromatic hydrocarbon analyses of the variegated claystone and black shale sam- 
ples. Ultimate deposition and preservation of continental plant material in the deep sea is signified by alkane predominances $\mathrm{C}_{29}$ and $\mathrm{C}_{31}$ abundant long-chain alkanes, and their odd-carbon predominances.

\section{Bound Nonaromatic Hydrocarbons}

Bound aliphatic hydrocarbons comprised $\leq 7 \%$ of the saponifiable lipid, representing concentrations of $<1$ to $15 \mu \mathrm{g} / \mathrm{g}$ and unbound/bound ratios of $<1$ to 200 (Table 3 ). No apparent trend was evident between the concentrations of the bound hydrocarbon concentrations and those of the respective total lipid extracts. With the exception of the variegated claystone, unbound/bound ratios agreed with values reported from other studies (Van Vleet and Quinn, 1979; Meyers et al., in press). Although Morris and Calvert (1975) proposed that sediment binding of lipid is purely a function of grain size, results of the present study suggest that sediment binding may also include such factors as degree of hydrocarbon unsaturation, branching, chain length (Meyers and Oas, 1978), and mineralogy (Meyers and Quinn, 1973).

The alkane distribution in the variegated claystone (603B-29-1) ranged from $\mathrm{C}_{18}$ through $\mathrm{C}_{33}$, maximized at $\mathrm{C}_{20}$, and was dominated by shorter-chain homologs (Fig. 1). The source of $\mathrm{C}_{20}$ has not been determined, but may derive from sulfate-reducing bacteria (Hunt, 1979). The lack of marine organic matter contribution to this bound lipid fraction was based on the absence of compounds $\mathrm{C}_{17}$ and $\mathrm{C}_{19}$. A maximum at $\mathrm{C}_{29}$ in the long-chain range and an OEP $\left(\mathrm{C}_{27}-\mathrm{C}_{31}\right)$ of 1.7 provided evidence for inputs by higher plant waxes.

In Section 603B-33,CC, $<0.3 \%$ of the bound lipid extract was composed of the nonaromatic hydrocarbon fraction. Alkanes ranged from $\mathrm{C}_{18}$ to $\mathrm{C}_{33}$ with a maximum peak at $C_{20}$. In light of the $\delta^{13} \mathrm{C}$ of $-24.7 \%$ and $\mathrm{C} / \mathrm{N}$ ratio of 40 , the longer-chain alkanes were probably derived from terrigenous organic matter although the OEP of 0.8 suggests that these compounds may have been altered.

Bound alkanes in Section 603B-34-1 were unimodally distributed, with a predominating peak at $\mathrm{C}_{20}$. Compounds with chain lengths $<\mathrm{C}_{25}$ were substantially more abundant than those $\geq C_{25}$, compounds that represented $<0.1$ of the predominating peak (Table 3 ).

The alkane distribution in Section 603B-34-2 ranged from $\mathrm{C}_{18}$ to $\mathrm{C}_{32}$, with a peak of maximum abundance at $\mathrm{C}_{20}$. The short-chain alkanes were represented solely by even-carbon compounds. Both even-carbon and odd-carbon compounds were identified in the long-chain range, but were of a lower relative abundance than the shortchain compounds. Some alteration of the long-chain compounds probably occurred, based on the OEP of 1.1.

The alkane distribution in Section 603B-36-1 ranged from $\mathrm{C}_{20}$ to $\mathrm{C}_{28}$ and had a predominating peak at $\mathrm{C}_{20}$. The carbon preferences was not typical of a biogenic marine or biogenic terrestrial input (Table 3).

Although the variegated claystone and black shale samples differed in geologic age and in sediment composition, the bound alkane distributions were similar: the alkane distributions were dominated by shorter chain compounds, peaks of maximum abundance were observed at $\mathrm{C}_{20}$ or $\mathrm{C}_{22}$, and the longer-chain counterparts lacked odd-carbon predominance. Using the unbound $n$-alkane distributions as a means of comparison, there was very little evidence of input by continentally derived alkanes in the bound hydrocarbon fraction.

\section{Unbound Fatty Acid}

Fatty acid concentrations relative to the total unbound lipid concentration did not appear to be related to sediment depth (Table 4). Lithologic differences, such as sediment texture and mineralogy, between the variegated claystone and black shales may have been responsible for the higher percentage of unbound fatty acids (Morris and Calvert, 1975) in Section 603B-29-1 compared to the other sediment samples.

The fatty acid distribution in the variegated claystone (603B-29-1) was representative of contributions from continental plant waxes: it was dominated by $\mathrm{C}_{30}$, and compounds $\geq \mathrm{C}_{22}$ composed a large proportion of the total saturated compounds (Fig. 2). Even-chain compounds dominated this distribution, although the longer chain acids may have undergone some alteration (even-odd predominance [EOP] of 1.6; because even-carbon compounds generally predominate over biogenically derived fatty acids, in the present text, the index is referred to as even-odd predominance). Anteiso acids $\mathrm{C}_{17}, \mathrm{C}_{19}$ and $\mathrm{C}_{21}$, which had low relative abundances, and $\mathrm{C}_{18}$, the most abundant short-chain compound, may have been microbially derived. Matsuda and Koyama (1977) have reported similar observations resulting from microbial inputs.

Fatty acid analyses of the black shale samples offered evidence for terrestrial organic matter input and microbial activity. In Sample 603B-33,CC and Section 603B34-1 the fatty acid distributions were dominated by $\mathrm{C}_{16}$ and $\mathrm{C}_{18}$, compounds that generally undergo preferential degradation (Table 4; Fig. 2). Shallow-water conditions, present during initial deposition of these sediments, may have been suitable for microbial activity. However, the low relative abundances of the monoenoic fatty acids and anteiso fatty acids suggest that microbial activity was probably not extensive in these samples (Gaskell et al., 1975).

Dominance by compounds $\mathrm{C}_{16}$ and $\mathrm{C}_{18}$ in the presence of long-chain compounds in these cores suggests that the short-chain acids may not have been utilized so readily as the short-chain $n$-alkanes. Even-carbon predominance of short-chain fatty acids in ancient sediments has been shown to be common. Even-carbon fatty acid predominances have been observed in both the Devonian Antrim shale and Soudan shale $\left(\sim 2.7 \times 10^{9}\right.$ years) although the respective $n$-alkanes lacked odd-carbon predominance (Van Hoeven et al., 1969).

The Section 603B-34-2 fatty acid fraction was gravimetrically analyzed although no quantitative determination was obtained. Gas chromatographic analysis of this sample showed a change in fatty acid distribution compared to the younger samples. In fatty acid distribution, $\mathrm{C}_{24}$ was the dominating compound, fatty acids $<\mathrm{C}_{22}$ were absent, and odd-carbon, anteiso, and monoenoic fatty acids were not detected. This distribution indicated 
that either extensive degradation eliminated the more labile short-chain fatty acids or that laboratory recovery of this fraction was incomplete.

In Section 603B-36-1, the fatty acid distribution was dominated by $\mathrm{C}_{16}, \mathrm{aiC}_{21}$ and $\mathrm{C}_{20: 1}$ and many saturated fatty acids were absent. A $\delta^{13} \mathrm{C}$ value of $-27.1 \%$ and an alkane maximum at $\mathrm{C}_{31}$ in the nonaromatic hydrocarbon fraction argue against substantial organic matter contribution by marine phytoplankton. Although $\mathrm{C}_{30}$ is typical of continentally derived fatty acids, the lack of compounds in the higher molecular weight range is not typical of inputs from terrestrial organic matter.

\section{Bound Fatty Acids}

Fatty acids comprised a small percentage $(<3.5 \%)$ of the alkaline-hydrolyzed lipid (Table 4 ). Fatty acid concentrations were one to two orders of magnitude less than the unbound fractions. These concentration differences may have been a function of organic-matter richness and reduced oxidation, factors that may have led to the preservation of the more labile unbound compounds. Results of the present study complement Aizenshtat et al.'s (1973) findings of Gulf of Mexico organic-carbonpoor, deep-sea sediments (20 and $103 \mathrm{~m})$. Aizenshtat et al. (1973) found that the isolation of bound fatty acids and the absence of unbound counterparts were attributed to a higher sediment oxidizing potential and a lower organic carbon concentration.

The distribution of bound fatty acids in Section 603B29-1 was dominated by $\mathrm{C}_{28}$ and $\mathrm{C}_{30}$ (Fig. 4). Peaks of maximum abundance generally corresponded with those compounds dominating the unbound fraction, with the exception of $\mathrm{C}_{29}$ (Fig. 3). The greater proportion of longchain fatty acids suggested that these lipids were probably derived from terrestrial sources (Table 4). A relatively larger number of monoenoic and short-chain compounds were detected in the bound fraction compared to the unbound fraction, a finding that has been observed both in this study and others (Brassell et al., 1978).

Bound fatty acids in Section 603B-33,CC were dominated by $\mathrm{C}_{24}$ and $\mathrm{C}_{26}$ (Fig. 4). These predominances do not coincide with those observed in the unbound fatty acid fraction. This finding suggests that the type of inputs to the bound and unbound fatty acid fractions were different, although, in general, from terrestrially derived organic matter.

In Section 603B-34-1, $\mathrm{C}_{16}$ dominated the fatty acid distribution. Greater relative abundances of short-chain fatty acids, including $\mathrm{C}_{16: 1}$, may be representative of inputs from microbial activity. The even-carbon preference of the short-chain fatty acids $\left(\mathrm{EOP}=22.1 ; \mathrm{C}_{16}-\mathrm{C}_{20}\right)$ indicated that these compounds had not been extensively altered.

Fatty acids in Section 603B-34-2 ranged from $\mathrm{C}_{16}$ to $\mathrm{C}_{32}$ with $\mathrm{C}_{26}$ being the most relatively abundant compound. A smaller percentage of short-chain fatty acids, including monoenoic compounds $(1 \%)$, suggested a reduction in microbial activity in the biosynthesis of these compounds.

The bound fatty acid distribution in Section 603B-36-1 was broader than that for the unbound fraction, although the general trends were similar (Figs. 3, 4). Although there were no branched fatty acids compounds generally indicative of microbial contribution (Gaskell et al., 1975), the concentrations may have been below the GC detection threshold.

The short-chain fatty acids and the unsaturated bound fatty acids generally exceeded their unbound counterparts, in number, in the samples analyzed in this study. This finding supports observations of enhanced preservation of sediment-bound compounds (Aizenshtat et al., 1973). Such a reduction in reactivity may have resulted from the presence of lipophilic humiclike material and/ or binding by clay mineral (Smith et al., 1983).

\section{SUMMARY}

Organic-matter-rich Upper Cretaceous claystones were sampled from DSDP Hole 603B, lower continental rise off North America. $\delta^{13} \mathrm{C}$ values of -23 to $-27 \%$, C/N ratios of 32 to 72 , unbound $n$-alkanes $\mathrm{C}_{29}$ and $\mathrm{C}_{31}$, unbound $n$-fatty acids $\mathrm{C}_{28}$ and $\mathrm{C}_{30}$, and bound $n$-fatty acids $\mathrm{C}_{24}, \mathrm{C}_{26}$, and $\mathrm{C}_{28}$ suggested that the organic matter in these sediments had a continental provenance. Both turbiditic emplacement of sediments of the lower continental rise and reduced sea-surface productivity in the North Atlantic Ocean would account for the terrigenous nature of the organic matter. The organic richness of the sediments supports the theory of diminished oxygen in the oceans during the period referred to as the Cretaceous Anoxic Event.

\section{ACKNOWLEDGMENTS}

The authors would like to thank Dr. P. Meyers for providing the DSDP samples and Ms. Margarita Conkright for performing the stable isotope analyses.

\section{REFERENCES}

Aizenshtat, Z., Baedecker, M. J., and Kaplan, I. R., 1973. Distribution and diagenesis of organic compounds in JOIDES sediment from the Gulf of Mexico and Western Atlantic. Geochim. Cosmochim. Acta, 37:1881-1898.

Anderson, T. F., and Arthur, M. A., 1983. Stable isotopes of oxygen and carbon and their application to sedimentologic and paleoenvironmental problems. In Arthur, M. A., Anderson, T. F., Kaplan, J. R., Veizer, J., and Land, L. S. (Eds.), Stable Isotopes in Sediment Geology. Soc. Econ. Paleontol. Mineral., Short Course No. 10, Dallas, pp. 80-107.

Boon, J. J., Rijpstra, W. I., and DeLeeuw, J. W., 1980. The occurrence of triglycerides in Namibian Shelf diatomaceous ooze. Geochim. Cosmochim. Acta, 44:131-134.

Boon, J. J., Van de Graaf, B., Schuyl, P. J. W., DeLange, F., and DeLeeuw, J. W., 1977. The mass spectrometry of iso and anteiso monoenoic fatty acids. Lipid, 12:717-721.

Bralower, T. J., and Thierstein, H. R., 1984. Low productivity and slow deep-water circulation in mid-Cretaceous oceans. Geology, 12:614-618.

Brassell, S. C., 1984. Aliphatic hydrocarbons of Cenomanian black shales and adjacent claystones. In Hay, W. W., Sibuet, J.-C., et al., Init. Repts. DSDP, 75, Pt. 2: Washington (U.S. Govt. Printing Office), $1019-1030$.

Brassell, S. C., Comet, P. A., Eglinton, G., Isaacson, P. J., McEvoy, J., Maxwell, J. R., Thomson, I. D., Tibbetts, P. J. C., and Volkman, J. R., 1978. Preliminary lipid analyses of Sections 440A-7-6, 440B-3-5, 440B-8-4, 440B-68-2, and 436-11-4, Legs 56 and 57. In Scientific Party, Init. Repts. DSDP, 56, 57, Pt. 2: Washington (U.S. Govt. Printing Office), 1367-1390.

Craig, H., 1953. The geochemistry of the stable carbon isotopes. Geochim. Cosmochim. Acta, 3:53-92. 
Curtis, C. D., 1980. Diagenetic alteration in black shales. J. Geol. Soc. London, 137:189-194.

Deroo, G., Herbin, J. P., Rouaché, J., and Tissot, B., 1979. Organic geochemistry of Cretaceous shales from DSDP Site 398, Leg 47B, eastern North Atlantic. In Sibuet, J.-C., Ryan, W. B. F., et al., Init. Repts. DSDP , 47, Pt. 2; Washington (U.S. Govt. Printing Office), 513-522.

Erdman, J. G., and Schorno, K. W., 1979. Geochemistry of carbon: DSDP Leg 43. In Tucholke, B. E., Vogt, P. R., et al., Init. Repts. $D S D P, 43$ : Washington (U.S. Govt. Printing Office), 651-655.

Farrington, J. W., and Tripp, B. W., 1977. Hydrocarbons in western North Atlantic surface sediments. Geochim. Cosmochim. Acta, $41: 1627-1641$.

Fischer, A. G., and Arthur, M. A., 1977. Secular variations in the pelagic realm. Soc. Econ. Paleontol. Mineral. Spec. Publ., 25:19-50.

Gaskell, S. J., Morris, R. J., Eglinton, G., and Calvert, S. E., 1975. The geochemistry of a recent sediment off northwest Africa. An assessment of source of input and early diagenesis. Deep-Sea Res., 22:777-789.

Hunt, J. A., 1979. How oil forms. In Gilluly J. (Ed.), Journal of Petroleum Geochemistry and Geology: San Francisco (W. H. Freeman), pp. 69-149.

Jenkyns, H. C., 1980. Cretaceous anoxic events from continents to oceans. J. geol. Soc. London, 137:171-188.

Joyce, R. M., 1985. Geochemical implications on the provenance and fate of organic rich deep-sea sediments [M.S. Thesis]. University of South Florida, St. Petersburg, Florida.

Katz, B. J., and Elrod, L. W., 1983. Organic geochemistry of DSDP Site 467 , offshore California, middle Miocene to lower Pliocene strata. Geochim. Cosmochim. Acta, 47:389-396.

Mangini, M. E., 1983. A stable carbon isotope study of the food web in Bayboro Harbor, St. Petersburg, Florida [Master's Thesis]. University of South Florida, St. Petersburg, Florida.

Matsuda, H., and Koyama, T., 1977. Early diagenesis of fatty acids in lacustrine sediments. I. Identification and distribution of fatty acids in recent sediments from a freshwater lake. Geochim. Cosmochim. Acta, 41:777-783.

Metcalfe, L. D., Schmitz, A. A., and Pelka, J. R., 1966. Rapid preparation of fatty acid esters from lipids for gas chromatography analysis. Anal. Chem., 38:514-515.

Meyers, P. A., and Oas, T. G., 1978. Comparison of association of different hydrocarbons with clay particles in simulated sea water. Environ. Sci. Technol., 12:934-937.

Meyers, P. A., Powaser, J. M., and Dunham, K. W., in press. Geolipids of late Cenozoic sediments from the western flank of the East Pacific Rise, Deep Sea Drilling Project Leg 92. In Leinen, M. Rea, D., et al., Init. Repts. DSDP, 92: Washington (U.S. Govt. Printing Office).
Meyers. P. A., and Quinn, J. G., 1973. Factors affecting the association of fatty acids with mineral particles in seawater. Geochim. Cosmochim. Acta, 37:1745-1759.

Morris, R. J., and Calvert, S. E., 1975. Fatty acid uptake by marine sediment particles. Geochim. Cosmochim. Acta, 39:377-381.

Muller, P. J., 1977. C/N ratios in Pacific deep-sea sediments. Effect of inorganic ammonium and organic nitrogen compounds sorbed by clays. Geochim. Cosmochim. Acta, 41:765-776.

Prahl, F. G., Bennett, J. T., and Carpenter, R., 1980. The early diagenesis of aliphatic hydrocarbons and organic matter in sedimentary particulates from Dabob Bay, Washington. Geochim. Cosmochim. Acta, 44:1967-1976.

Ryan, W., and Cita, M. B., 1977. Ignorance concerning episode of ocean wide stagnation. Mar. Geol., 23:197-215.

Scalan, R. S., and Smith, J. E., 1970. An improved measure of the odd-even predominance in the normal alkanes of sediment extracts and petroleum. Geochim. Cosmochim. Acta, 34:611-620.

Schlee, J. S., and Jansa, L. F., 1981. The paleoenvironment and development of the eastern North American continental margin. Oceanol. Acta, 4:71-80.

Simoneit, B. R. T., 1979. Organic geochemistry of the shales from the northwestern Proto-Atlantic, DSDP Leg 43. In Tucholke B. E. Vogt, P. R. et al., Init. Repts. DSDP, 43: Washington (U.S. Govt. Printing Office), 643-649.

Smith, D. J., Eglinton, G., and Morris, R. J., 1983. The lipid chemistry of an interfacial sediment from the Peru Continental Shelf: fatty acids, alcohols, aliphatic ketones and hydrocarbons. Geochim. Cosmochim. Acta, 47:2225-2232.

Tulloch, A. P., 1976. Chemistry of waxes of higher plants. In Kolattukudy, P. E., (Ed.), Chemistry and Biochemistry of Natural Waxes: Amsterdam (Elsevier), pp. 235-288.

Van Graas, G., 1983. Origin of the organic matter in a Cretaceous black shale deposit in the Central Apennines (Italy). In Bjoroy, M., Albrecht, P., Cornford, C., de Groot, K., Eglinton, G., et al. (Eds.), Advances in Organic Geochemistry, 1981: Chichester (John Wiley), pp. 471-476.

Van Hoeven, W., Maxwell, J. R., and Calvin, M., 1969. Fatty acids and hydrocarbons as evidence of life processes in ancient sediments and crude oils. Geochim. Cosmochim. Acta, 33:871-881.

Van Vleet, E. S., and Quinn, J. G., 1979. Early diagenesis of fatty acids and isoprenoid alcohols in estuarine and coastal sediments. Geochim. Cosmochim, Acta, 43:289-303.

Wakeham, S. G., 1982. Organic matter from a sediment trap experiment on the equatorial N. Atlantic: wax esters, steryl esters, triacylglycerols and alkyldiacylglycerols. Geochim. Cosmochim. Acta, 46:2239-2257.

Date of Initial Receipt: 6 February 1985

Date of Acceptance: 23 September 1985 